\title{
Profile of recovery after general anaesthesia
}

\author{
M HERBERT, T E J HEALY， J B BOURKE， I R FLETCHER， J M ROSE
}

\begin{abstract}
The duration of impairment of mental functioning after anaesthesia was studied in 55 patients undergoing hernia repair who were divided into three groups in which the method of induction of anaesthesia (intravenous or inhalational) and ventilation (spontaneous or controlled) was varied. Performance in a five minute serial reaction time test and subjective estimates of coordination were assessed four times a day for two complete postoperative days and were compared with those in a control group of orthopaedic patients in hospital. After considerable impairment initially, reaction times in all groups gradually returned towards control values, but in patients breathing spontaneously during anaesthesia impairment recurred during the second postoperative day.

These results suggest that such patients should be advised not to undertake hazardous tasks such as driving a car for at least 48 hours after a general anaesthetic. Discrepancies between subjective and objective assessments of impairment also suggest that patients should not rely on their own assessments of fitness to drive.
\end{abstract}

\section{Introduction}

It is accepted that patients who submit to general anaesthesia in day case units should be cautioned against carrying out potentially dangerous activities, such as driving a car or operating

\footnotetext{
Behavioural Sciences Section, Department of Psychiatry, Nottingham University Medical School, Nottingham NG7 2UH

M HERBERT, BA, PHD, senior lecturer

Department of Anaesthesia, Nottingham University Medical School $T$ E J HEALY, MD, FFARCS, reader in anaesthesia

I R FLETCHER, MRCP, FFARCS, lecture

J M ROSE, MB, CHB, clinical assistant

Department of Surgery, Nottingham University Medical School J B BOURKE, MB, FRCS, senior lecturer

Correspondence to: Dr M Herbert.
}

complicated machinery, at least until the residual effects of their general anaesthetic have worn off. How long patients' faculties are impaired postoperatively, however, is controversial. A widely accepted view is that mental function is fully restored after a night's sleep and, therefore, that the caution not to undertake hazardous tasks should extend for about 24 hours postoperatively. Havard's recommendation ${ }^{1}$ that about 48 hours be adopted has been considered unnecessary in the light of current practice or opinion. ${ }^{2}$

The suggestion that higher mental functions have returned to unimpaired levels within a few hours of surgery receives apparent support from several studies. Despite wide diversity in the use of premedication and variation in induction and maintenance agents, few reports find evidence of impaired performance for longer than eight hours. Even when relatively prolonged effects occur, patients are generally considered to be fit to drive within 24 hours. $^{3}$

The difficulties in drawing firm conclusions from data provided by heterogeneous groups administered varying doses of different anaesthetic drugs were pointed out by Epstein. ${ }^{4}$ Herbert also drew attention to the fact that tests can vary widely in the sensitivity of their response to stressors. ${ }^{5}$ It is particularly important to use maximally sensitive tests when considering residual impairment that may not be clinically obvious. An additional difficulty affecting conclusions about the duration of impairment is the presumption that once performance has returned to unimpaired levels deterioration does not occur. As a result patients' abilities are not usually monitored beyond the point at which performance has returned to the baseline value. The assumption, though, may be untenable. Normal diurnal variation in performance might well result in the effects re-emerging even after the patient has apparently fully recovered.

In the present study we monitored the profile of performance after standard anaesthetic procedures for two complete postoperative days.

\section{Patients and methods}

Fifty five men scheduled for elective repair of hernia took part in the study. Apart from the indications for surgery, all were fit. The test procedure was explained to each patient and informed consent obtained. Surgical intervention took place between mid-morning and mid-afternoon. 


\section{ANAESTHETIC PROCEDURE}

Patients were allocated randomly to one of two anaesthetic groups for comparison with a control group. A standard anaesthetic procedure was used consisting of oral premedication with diazepam $10 \mathrm{mg}$ one hour before induction of anaesthesia with thiopentone $250 \mathrm{mg}$ and maintenance with halothane $0.5-1.5 \%$ and nitrous oxide and oxygen (6 and $3 \mathrm{l} / \mathrm{min}$ respectively). Controlled ventilation was used in 22 patients, who were given suxamethonium and alcuronium as muscle relaxants and were intubated. Twenty one patients breathed spontaneously. Subsequently, a third anaesthetic group was formed consisting of 12 patients in whom anaesthesia was induced with halothane and who breathed spontaneously.

Twelve men in hospital for orthopaedic operations who had not had an operation for at least two weeks before testing served as controls. The mean ages of the groups were 51.5 years in the patients given standard anaesthesia who received ventilation; $49 \cdot 8$ years in the patients given standard anaesthesia who breathed spontaneously; 53.5 years in the patients in whom anaesthesia was induced with halothane; and $45 \cdot 7$ years in the controls. There were no significant differences in ages between the groups.

\section{TESTS}

Choice serial reaction time-A portable cassette recorder was modified as previously described. ${ }^{6}$ Patients were instructed to press one of four buttons corresponding geometrically to one of four lights that could be illuminated. Pressing the button, whether correct or incorrect, extinguished the light and brought on another, to which the patient then responded. This test lasted for five minutes. Responses were recorded on magnetic tape, which was subsequently analysed to find the mean reaction time over the test.

Visual analogue scales-Patients rated their mood using 18 lines $10 \mathrm{~cm}$ long that indicated various affective dimensions (fig 1). There

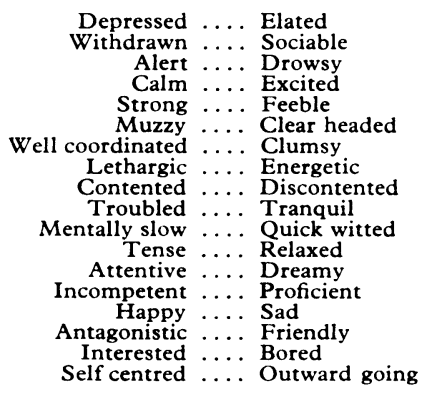

FIG $1-$ Visual analogue scales.

were three parallel versions of the scales. On each version the order and polarity of the lines were randomised to prevent stereotypy of response. Responses on this mood inventory were scored in millimetres, and after standard factor analysis each score was then differentially weighted according to estimates provided by Herbert et al. ${ }^{7}$
This technique appears partly to overcome the problem of subjective bias in responses, since patients do not know the value of the weighting $\mathbb{D}$ given to each line. In addition, calculating such scores appears to be $\stackrel{\varrho}{c}$ a more sensitive way of monitoring changes than simply looking at $\overparen{\Omega}$ changes on individual lines. ${ }^{8}$

Test procedure-Patients were introduced to the visual analogue scales and reaction time test on admission to hospital the day before $\mathbb{D}$ the operation was scheduled. Assessments of preoperative mood and $\infty$ reaction time were then made. On the day of the operation, per- $\Omega$ formance and mood were recorded 90 minutes after the patient had returned to the ward from the recovery room. Further measurements were taken at $0830,1100,1330$, and 1630 on the next two days. On each occasion patients completed the tests in bed, with the screens drawn to prevent distractions.

\section{Results}

\section{REACTION TIMES}

A preliminary analysis of variance of the reaction times in all $\vec{\omega}$ groups across each measurement point showed a significant group $\times \frac{\mathrm{O}}{\partial}$ time interaction $(\mathrm{F}=2.48 ; \mathrm{df}=27,547 ; \mathrm{p}<0.01)$. Subsequently, 3 $t$ tests for unrelated samples were used to determine the significance of differences in performance between the control patients and those $\mathbb{O}$ who received anaesthesia. The level of significance was set at $\mathrm{p}=0.05$ (one tailed test). Figure 2 and table I show the mean reaction times in the four groups before operation, 90 minutes after regaining. consciousness, and throughout the two days after the operation.

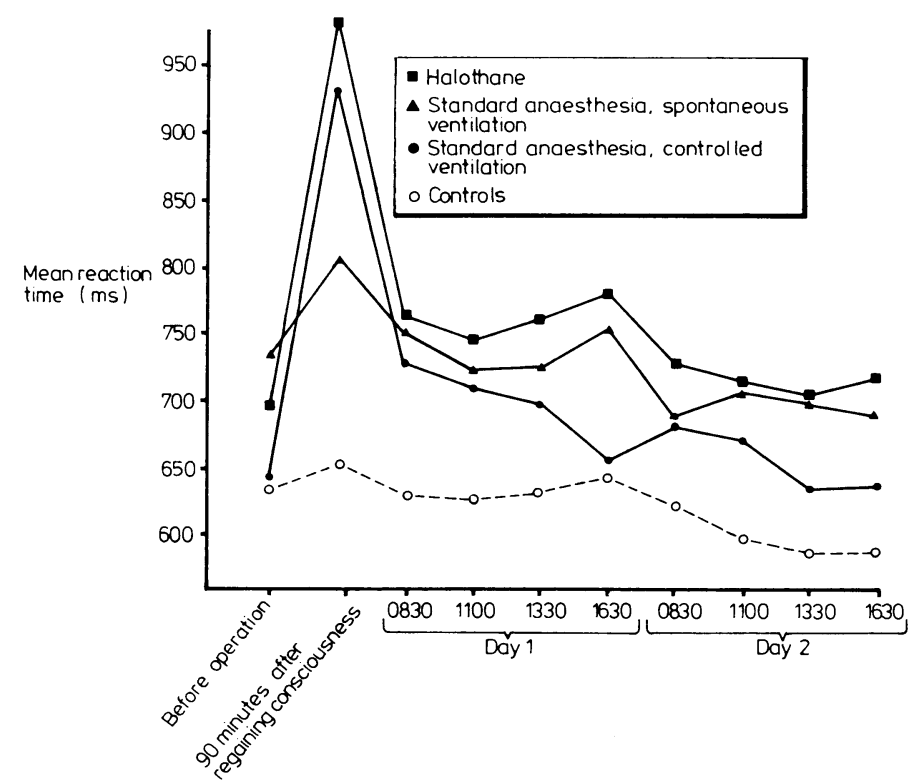

FIG 2-Mean reaction times in four choice test.

TABLE I-Mean reaction times in each group throughout study

\begin{tabular}{|c|c|c|c|c|c|c|c|c|c|c|}
\hline & \multirow{2}{*}{$\begin{array}{c}\text { Before } \\
\text { operation }\end{array}$} & \multirow{2}{*}{$\begin{array}{l}90 \text { minutes } \\
\text { after regaining } \\
\text { consciousness }\end{array}$} & \multicolumn{4}{|c|}{ Postoperative day 1} & \multicolumn{4}{|c|}{ Postoperative day 2} \\
\hline & & & 0830 & 1100 & 1330 & $\overline{1630}$ & 0830 & 1100 & 1330 & 1630 \\
\hline \multicolumn{11}{|c|}{ Patients given standard anaesthesia, controlled ventilation } \\
\hline $\begin{array}{l}\text { Mean reaction time (ms) } \\
\text { SEM } \\
\text { No of patients }\end{array}$ & $\begin{array}{c}643 \cdot 6 \\
18 \cdot 7 \\
22\end{array}$ & $\begin{array}{l}939 \cdot 4 \\
81 \cdot 2 \\
19\end{array}$ & $\begin{array}{c}728 \cdot 3 \\
34 \cdot 7 \\
22\end{array}$ & $\begin{array}{r}707.5 \\
41 \cdot 5 \\
21\end{array}$ & $\begin{array}{c}697 \cdot 9 \\
29 \cdot 3 \\
20\end{array}$ & $\begin{array}{c}657 \cdot 3 \\
18.5 \\
21\end{array}$ & $\begin{array}{c}680 \cdot 0 \\
36 \cdot 9 \\
21\end{array}$ & $\begin{array}{c}669 \cdot 3 \\
42 \cdot 9 \\
22\end{array}$ & $\begin{array}{c}633 \cdot 2 \\
19 \cdot 0 \\
21\end{array}$ & $\begin{array}{r}635 \cdot 9 \\
19 \cdot 3 \\
21\end{array}$ \\
\hline \multicolumn{11}{|c|}{ Patients given standard anaesthesia, spontaneous ventilation } \\
\hline $\begin{array}{l}\text { Mean reaction time (ms) } \\
\text { SEM } \\
\text { No of patients }\end{array}$ & $\begin{array}{l}734 \cdot 3 \\
87 \cdot 4 \\
21\end{array}$ & $\begin{array}{c}807.0 \\
49.9 \\
18\end{array}$ & $\begin{array}{c}749.8 \\
52.8 \\
20\end{array}$ & $\begin{array}{l}723 \cdot 0 \\
45.3 \\
21\end{array}$ & $\begin{array}{l}724 \cdot 4 \\
46 \cdot 8 \\
21\end{array}$ & $\begin{array}{r}752 \cdot 4 \\
52 \cdot 7 \\
21\end{array}$ & $\begin{array}{c}688 \cdot 3 \\
41.1 \\
21\end{array}$ & $\begin{array}{c}707 \cdot 2 \\
44 \cdot 4 \\
21\end{array}$ & $\begin{array}{l}696 \cdot 8 \\
39 \cdot 6 \\
21\end{array}$ & $\begin{array}{r}687.9 \\
39.0 \\
21\end{array}$ \\
\hline \multicolumn{11}{|c|}{ Patients given halothane to induce anaesthesia } \\
\hline $\begin{array}{l}\text { Mean reaction time (ms) } \\
\text { SEM } \\
\text { No of patients }\end{array}$ & $\begin{array}{c}695 \cdot 7 \\
41 \cdot 1 \\
10\end{array}$ & $\begin{array}{c}986 \cdot 7 \\
67 \cdot 6 \\
11\end{array}$ & $\begin{array}{c}763 \cdot 8 \\
48 \cdot 9 \\
12\end{array}$ & $\begin{array}{c}744 \cdot 4 \\
49 \cdot 7 \\
11\end{array}$ & $\begin{array}{c}761 \cdot 5 \\
60 \cdot 3 \\
12\end{array}$ & $\begin{array}{c}780 \cdot 0 \\
69 \cdot 8 \\
12\end{array}$ & $\begin{array}{l}726 \cdot 2 \\
53 \cdot 3 \\
12\end{array}$ & $\begin{array}{c}713 \cdot 8 \\
58 \cdot 1 \\
12\end{array}$ & $\begin{array}{c}703 \cdot 8 \\
43 \cdot 8 \\
12\end{array}$ & $\begin{array}{c}716 \cdot 1 \\
53 \cdot 2 \\
12\end{array}$ \\
\hline \multicolumn{11}{|c|}{ Controls } \\
\hline $\begin{array}{l}\text { Mean reaction time }(\mathrm{ms}) \\
\text { SEM } \\
\text { No of patients }\end{array}$ & $\begin{array}{l}633 \cdot 0 \\
37 \cdot 1 \\
12\end{array}$ & $\begin{array}{l}653 \cdot 0 \\
49 \cdot 6 \\
11\end{array}$ & $\begin{array}{c}631 \cdot 0 \\
42 \cdot 9 \\
12\end{array}$ & $\begin{array}{l}628.8 \\
37.7 \\
12\end{array}$ & $\begin{array}{l}633 \cdot 3 \\
36 \cdot 1 \\
12\end{array}$ & $\begin{array}{l}644 \cdot 0 \\
46 \cdot 1 \\
12\end{array}$ & $\begin{array}{l}622 \cdot 1 \\
39 \cdot 8 \\
11\end{array}$ & $\begin{array}{c}595 \cdot 3 \\
25.5 \\
12\end{array}$ & $\begin{array}{l}587 \cdot 0 \\
23 \cdot 1 \\
12\end{array}$ & $\begin{array}{c}586 \cdot 7 \\
29 \cdot 2 \\
12\end{array}$ \\
\hline
\end{tabular}


TABLE II-Mean coordination scores in each group throughout study

\begin{tabular}{|c|c|c|c|c|c|c|c|c|c|c|}
\hline & \multirow{2}{*}{$\begin{array}{c}\text { Before } \\
\text { operation }\end{array}$} & \multirow{2}{*}{$\begin{array}{c}90 \text { minutes } \\
\text { atter regaining } \\
\text { consciousness }\end{array}$} & \multicolumn{4}{|c|}{ Postoperative day 1} & \multicolumn{4}{|c|}{ Postoperative day 2} \\
\hline & & & 0830 & 1100 & 1330 & 1630 & 0830 & 1100 & 1330 & 1630 \\
\hline \multicolumn{11}{|c|}{ Patients given standard anaesthesia, controlled ventilation } \\
\hline $\begin{array}{l}\text { Mean } \\
\text { SEM }\end{array}$ & $\begin{array}{c}-1 \cdot 267 \\
0 \cdot 21\end{array}$ & $\begin{array}{l}0.547 \\
0.76\end{array}$ & $\begin{array}{c}-0.170 \\
0.24\end{array}$ & $\begin{array}{c}-0.348 \\
0.24\end{array}$ & $\begin{array}{c}-0.318 \\
0.22\end{array}$ & $\begin{array}{c}-0.591 \\
0.26\end{array}$ & $\begin{array}{c}-0.585 \\
0.22\end{array}$ & $\begin{array}{c}-0.635 \\
0.20\end{array}$ & $\begin{array}{c}-0.828 \\
0.22\end{array}$ & $\begin{array}{c}-0.790 \\
0.25\end{array}$ \\
\hline \multicolumn{11}{|c|}{ Patients given standard anaesthesia, spontaneous ventilation } \\
\hline $\begin{array}{l}\text { Mean } \\
\text { SEM }\end{array}$ & $\begin{array}{c}-0.535 \\
0.14\end{array}$ & $\begin{array}{l}1 \cdot 102 \\
0 \cdot 14\end{array}$ & $\begin{array}{l}0.198 \\
0.19\end{array}$ & $\begin{array}{l}0.175 \\
0 \cdot 16\end{array}$ & $\begin{array}{l}0.026 \\
0.18\end{array}$ & $\begin{array}{c}-0.182 \\
0.22\end{array}$ & $\begin{array}{c}-0.329 \\
0.16\end{array}$ & $\begin{array}{c}-0.417 \\
0.21\end{array}$ & $\begin{array}{c}-0.454 \\
0.20\end{array}$ & $\begin{array}{c}-0.447 \\
0.19\end{array}$ \\
\hline \multicolumn{11}{|c|}{ Patients given halothane to induce anaesthesia } \\
\hline $\begin{array}{l}\text { Mean } \\
\text { SEM }\end{array}$ & $\begin{array}{c}-1.555 \\
0.32\end{array}$ & $\begin{array}{l}0.634 \\
0.48\end{array}$ & $\begin{array}{c}-0.010 \\
0.39\end{array}$ & $\begin{array}{c}-0.241 \\
0.34\end{array}$ & $\begin{array}{c}-0.348 \\
0.35\end{array}$ & $\begin{array}{c}-0.427 \\
0.40\end{array}$ & $\begin{array}{c}-0.682 \\
0.32\end{array}$ & $\begin{array}{c}-0.841 \\
0.36\end{array}$ & $\begin{array}{c}-0.939 \\
0.39\end{array}$ & $\begin{array}{c}-0.952 \\
0.37\end{array}$ \\
\hline
\end{tabular}

There was no significant difference between the groups in their levels of preoperative functioning. Compared with the controls the three groups given anaesthesia showed slowed reaction times 90 minutes after regaining consciousness (patients given standard anaesthesia, controlled ventilation, $\mathrm{p}<0.01$; patients given standard anaesthesia, spontaneous breathing, $\mathrm{p}<0.05$; patients with anaesthesia induced with halothane $\mathrm{p}<0.005)$. The impairment of reaction times persisted into the first postoperative day in the patients in whom anaesthesia was induced with halothane $(\mathrm{p}<0.05$ at 0830,1100 , and 1330).

There was clear evidence of impaired performance during the second postoperative day: results in the group given standard anaesthesia who breathed spontaneously were significantly poorer than those in controls at 1100,1330 , and 1630 (all p<0.05), as were the results in the patients in whom anaesthesia was induced with halothane ( $p<0.05, p<0.02$, and $p<0.05$ respectively). Patients in whom ventilation was controlled during anaesthesia showed no significant differences in performance from controls at any time on the days after the operation.

\section{VISUAL ANALOGUE SCALES}

Since visual analogue scales are not subject to practice effects, direct comparison between each patient's scores on admission and postoperatively was possible using the $t$ test for paired samples (table II).

Figure 3 shows coordination scores plotted against the postoperative measurement points. These scores are not absolute values but represent the relative scores in each group using a standardised scale derived from previous factor analysis. ${ }^{7}$ Immediately after the operation coordination was considerably decreased in all anaesthetic groups (all $p<0.001$ ). Although there was a general trend back towards the preoperative score as time progressed, the group who received controlled ventilation felt their condition to be significantly impaired at all times postoperatively except at 1330 on the second day (all $\mathrm{p}<0.025)$. In the group given standard anaesthesia who

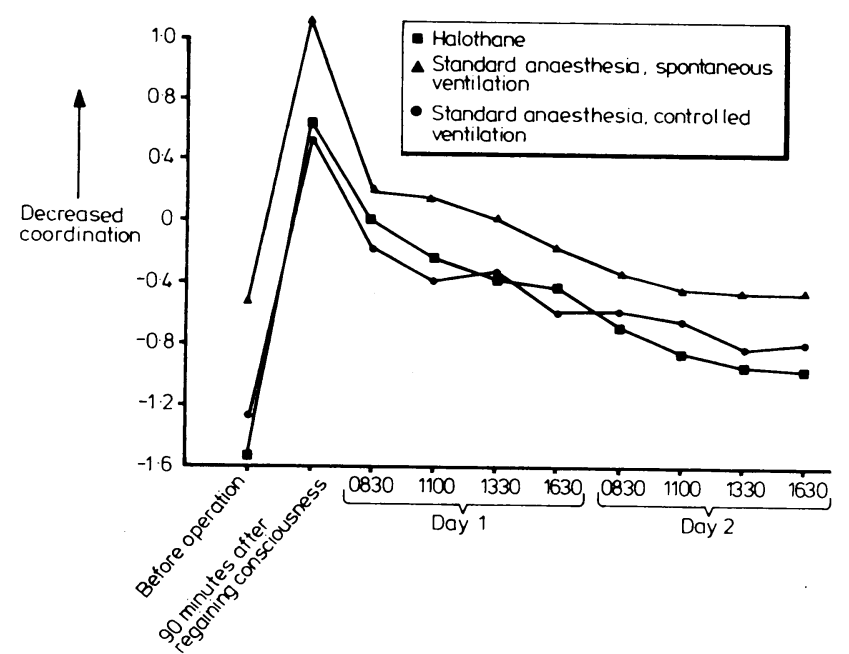

FIG 3-Mean self-assessed coordination scores derived from visual analogue scales. breathed spontaneously feelings of uncoordination persisted for much of the first day after the operation $(0830, p<0.005 ; 1100, p<0.005$; $1330, p<0.01$ ) but thereafter were indistinguishable from preoperative values. Patients in whom anaesthesia was induced with halothane felt uncoordinated throughout the entire postoperative period ( $p<0.025$ or less).

\section{Discussion}

In the present study patients' psychomotor abilities were monitored for two complete days after the day of operation by using a choice reaction time test. This test is sensitive to quite subtle alterations due to pharmacological agents ${ }^{9}$ including anaesthetics. ${ }^{10}$ Variation between patients was reduced by using a group of men undergoing routine elective herniorraphy.

Both subjective measures of coordination and objective measures of performance showed similar trends across the two days after general anaesthesia. Shortly after regaining consciousness patients showed a pronounced and expected impairment in the speed of responding to the reaction time test, a deficit that was mirrored in the subjective coordination scores. During the two subsequent days both variables gradually returned towards control or baseline values.

The patients in whom anaesthesia was induced with halothane continued to show signs of impairment even after a night's sleep, and this performance deficit persisted until early afternoon. Thus the caution not to carry out tasks demanding quick reactions for $\mathbf{2 4}$ hours after general anaesthesia would appear to be acceptable, since in all groups reactions were within control values by the afternoon after operation. The reaction time slowed again, however, during the second postoperative day in the group given standard anaesthesia who breathed spontaneously and the group in whom anaesthesia was induced with halothane, and was significantly slower than that in the controls from mid-morning onwards. This re-emergence of impaired reaction times two days after operation emphasises the importance of continuing testing beyond the point where patients have apparently recovered. Without such testing results of the present study would have concurred with those of earlier reports showing that the psychomotor consequences of general anaesthesia are fairly short lived. The present data, however, suggest that it would seem wise to extend the warning not to drive to at least 48 hours postoperatively.

Such a caution, though, appears to apply to those patients breathing spontaneously during operation. Those whose breathing was assisted during anaesthesia experienced no long term effects on performance. This differential effect between controlled and spontaneous ventilation suggests that despite attempts to make the depth of anaesthesia comparable between the groups, the use of a muscle relaxant in patients whose ventilation was controlled may have resulted in those patients receiving less halothane and consequently experiencing relatively less cortical depression during surgery.

Generally, the subjective experience of uncoordination followed the pattern of an initial severe impairment and a gradual return to preoperative values. Patients whose ventilation was controlled, however, whose performance was minimally 
affected, continued to report subjective feelings of impairment throughout most of the two postoperative days. The group who breathed spontaneously, on the other hand, had subjectively recovered to preoperative levels by the middle of the first day after the operation, but their performance was still impaired during the second day. This divergence between subjective and objective estimates of recovery is important and suggests that patients should be advised not to rely on their own judgment of fitness to drive. It should be pointed out to them that some aspects of mental ability may remain impaired even after they feel that they have made a full recovery.

We thank Trent Regional Health Authority for financial support and the ward staff for their help in this study.

\section{References}

${ }^{1}$ Havard JA. Medical aspects of fitness to drive. London: Medical Commission on Accident Prevention, 1976.

2 Baskett PJF, Vickers MD. General anaesthesia and driving. Lancet $1979 ; \mathrm{i}: 490$.
${ }^{3}$ Kortilla K, Linnoila M, Ertama P, Hakkinen S. Recovery and simulated driving after intravenous anaesthesia with thiopental, methohexital, propanidid or alphadione. Anesthesiology 1975;43:291-8.

' Epstein BS. Recovery from anesthesia. Anesthesiology $1975 ; 43: 285-8$.

${ }^{5}$ Herbert $M$. Assessment of performance in studies of anaesthetic agents. Br F Anaesth 1978;50:33-8.

${ }^{6}$ Wilkinson RT, Houghton D. Portable four-choice reaction time test with magnetic tape memory. Behavior Research Methods and Instrumentation $1975 ; 7: 441$.

${ }^{7}$ Herbert M, Johns MW, Dore C. Factor analysis of analogue scales measuring subjective feelings before and after sleep. Br $\mathcal{F ~ M e d ~ P s y c h o l ~}$ 1976;49:373-9.

${ }^{*}$ Herbert M, Bourke JB, Rose JM. The assessment of preoperative medication by a visual analogue technique. In: Oborne DJ, Gruneberg MM, Eiser JR, eds. Research in psychology and medicine. Vol 1. London: Academic Press, 1979.

${ }^{9}$ Jeffcoate WJ, Herbert $M$, Cullen $M H$, Hastings AG, Walder CP. Prevention of effects of alcohol intoxication by naloxone. Lancet 1979 ;ii 1157-9.

1" Scott A, Whitnam JG, Wilkinson RT, Whitten JEJ. Assessment of postoperative performance decrement using a serial four-choice reaction-time test. Proceedings of the Anaesthetic Research Society. Br J Anaesth 1980;52:629-30.

\title{
Method of sampling chorionic villi in first trimester of pregnancy under guidance of real time ultrasound
}

\author{
R H T WARD, B MODELL, M PETROU, F KARAGÖZL $\bar{U}$, E DOURATSOS
}

\begin{abstract}
Samples of chorionic villi were obtained in the first trimester by aspiration using a cannula passed transcervically under the guidance of real time ultrasound. In initial studies in $\mathbf{4 7}$ anaesthetised patients immediately before therapeutic abortion a method was developed giving a success rate of $89 \%$. In 10 patients successful sampling was performed as an outpatient procedure without anaesthesia. In all, seven diagnostic procedures were undertaken and four of the five unaffected pregnancies continued.

The technique of chorionic villous sampling using real time ultrasound is simple to learn and yields material for biochemical analysis and chromosomal study without the need for tissue culture. The exact obstetric risk, however, remains to be defined.
\end{abstract}

\section{Introduction}

The development of DNA analysis for fetal diagnosis, particularly of the haemoglobinopathies, ${ }^{1}$ provided the impetus to develop a simple and safe method of obtaining chorionic villous material early in pregnancy. In China blind sampling of

\footnotetext{
Department of Obstetrics and Gynaecology, School of Medicine, University College London, London WC1E 6AU

R H T WARD, MA, FRCOG, consultant and senior lecturer

B MODELL, MA, MRCPATH, consultant in perinatal medicine

M PETROU, BSC, research assistant

F KARAGÖZL,Ŭ, MD (Istanbul), research fellow

E DOURATSOS, MD (Athens), research fellow

Correspondence to: $\mathrm{Mr} \mathrm{R} \mathrm{H} \mathrm{T} \mathrm{Ward.}$
}

chorionic villi for determining the sex of the fetus reportedly has a low complication rate. ${ }^{2}$ In Russia a method using flexible biopsy forceps under ultrasound guidance has also been devised for fetal diagnosis of genetic sex linked conditions, and all 13 pregnancies that were allowed to continue after the procedure had a normal outcome. ${ }^{3}$

Mid-trimester diagnosis for the haemoglobinopathies by fetal blood sampling at fetoscopy carries an appreciable risk for the fetus $^{4}$ and may result in emotional and physical trauma associated with late therapeutic abortion in the $25 \%$ of cases in which this is indicated. A diagnostic technique for use in the first trimester would have the major advantage that termination of an affected pregnancy, when requested, could be undertaken under general anaesthesia at a safe and acceptable time for the patient.

A gene mapping method used for first trimester fetal diagnosis in three cases at risk for haemoglobinopathies has been described. ${ }^{5}$ In this paper we describe the obstetric technique and outline some of the problems encountered in early chorionic villous sampling.

\section{Patients and methods}

Initially the feasibility of obtaining chorionic villi was tested in anaesthetised patients before termination in the first trimester. In phase 1 (28 patients) either a 16 gauge Medicut cannula or a specially designed Portex cannula with one or more side holes was used, with suction provided by a $2 \mathrm{ml}$ or $5 \mathrm{ml}$ syringe. The siting of the cannula was monitored with linear array real time ultrasound (Toshiba SAL-20A) and samples examined in the laboratory under a dissecting microscope for the presence of villous material. In phase 2 (19 patients) the Portex cannula had an end hole and an aluminium obturator which could be curved appropriately and is visible in the ultrasound scan. A $20 \mathrm{ml}$ syringe provided greater suction. The presence of villous material was confirmed histologically. In phase 3 (14 patients) successful chorionic villous sampling was confirmed in 